\title{
Suppressing the Violence in the Brain by Neuroplasticity; Is it ethical?
}

\author{
Şiddetin Beyinde Nöroplastisite ile Baskılanması; Bu Etik midir?
}

\section{Sevgi Daşdemir ${ }^{1}$, Lamia Pınar ${ }^{2}$, Nesrin Çobanoğlu ${ }^{3}$}

${ }^{1}$ Gazi University Faculty of Medicine, Ankara, Turkey

${ }^{2}$ Gazi University Faculty of Medicine Department of Physiology, Ankara, Turkey

${ }^{3}$ Gazi University Faculty of Medicine Department of Medical Ethics and History, Ankara, Turkey

\section{ABSTRACT}

The phenomenon of violence which has been seen in all historical ages is a behavioral pathology and has increased in various communities and time and has never been exactly handled. Communities usually deal with the results instead of investigating the reasons of the violence and often tend towards to the treatment solutions with palliative methods, and try to suppress and prevent violence through various laws and criminal procedures. However, instead of focusing on the palliative methods, reasons of violence need to be investigated with scientific studies and new treatment methodologies need to be developed. This project has been suggested by a student who is a medical doctor candidate in order to contribute to the solution of the violence issue. The mechanisms of "neural plasticity depending on learning" forms the basis of this hypothesis Therefore, the possibility of creating cognitive and behavioral changes in humans with the learning methods that may lead to neuroplasticity, has been reviewed in the related literature. Additionally, the efficiency of this type of learning methods in preventing the violence and the ethical issues were discussed.

Key Words: Neuroplasticity, violence, ethics, epigenetics

Received: 09. 03. 2018

Accepted: 19. 09. 2018
ÖZET

Şiddet olgusu, tarihin bütün çağlarında var olan, çeşitli dönemlerde ve toplumlarda dozu artan ve tam olarak çözülememiş bir davranış patolojisidir. Toplumlar genellikle şiddetin nedenlerini araştırmak yerine sonuçları ile ilgilenir, palyatif tedavilere yönelir, çeşitli yasa ve cezai prosedürlerle şiddeti bastırmaya ve engellemeye çalışır. Halbuki, palyatif yöntemlere odaklanmak yerine şiddetin nedenleri bilimsel çalışmalarla araştırılmalı ve yeni tedavi yöntemleri geliştirilmelidir.Bu proje, şiddet sorununun çözümüne katkıda bulunmak için, tıp doktoru adayı olan bir öğrenci tarafından önerilmiştir. "Öğrenmeye bağlı nöral plastisite" mekanizmaları bu hipotezin temelini oluşturmaktadır. Bu nedenle, nöroplastisiteye yol açabilecek öğrenme yöntemlerinin, insanlarda bilişsel ve davranışsal değişiklikler yaratma olasılığı ile ilgili literatür gözden geçirilmiş ve şiddetin önlenmesinde bu tür öğrenme yöntemlerinin etkinliği ve bunun getireceği etik sorunlar tartışılmaktadır.

Anahtar Sözcükler: Nöroplastisite, şiddet, etik, epigenetik

Geliş Tarihi: 09. 03. 2018

Kabul Tarihi: 19. 09. 2018

Yazışma Adresi / Address for Correspondence: Sevgi Daşdemir, 6 ${ }^{\text {th }}$ Grade Medical Student Gazi University Faculty of Medicine, Ankara, Turkey E-mail: sevgidasdemir@gmail.com

CTelif Hakkı 2018 Gazi Üniversitesi Tıp Fakültesi - Makale metnine http://medicaljournal.gazi.edu.tr/ web adresinden ulaşılabilir.

(C) Copyright 2018 by Gazi University Medical Faculty - Available on-line at web site http://medicaljournal.gazi.edu.tr/

doi:http://dx.doi.org/10.12996/gmj.2018.106 


\section{INTRODUCTION}

Aggression and violence have threaten human life much more than the epidemic and the natural disaster from past to present (1). The answer of the question "Why is a human being aggressive?" is quite difficult. Aggression can be inherited from the ancestors and is sealed to the character of someone, or can be learned later with the impact of the current environment (2). In this review, it is explained that these two presences are closely related to each other.

Scientific studies show that the characteristic features of each individual are inherited from their parents by genes which are shaped together with the intellectual environment starting from early ages. Thus, shaping of the character, due to genetic inheritance, with the effect of environment, constitutes 'the epigenetic'. The Bobo-Doll experiment (Albert Bandura, 19611963) shows that children following aggressive behavioral patterns of their parents, showed more aggressive behaviors. It has been proven that abused persons who have been exploited in childhood and infancy exhibit similar behavior in their adult life(3). The opposite is also possible. The people, who have learned good values in their childhood, transfer their new genetic attachments to their children. Thus, a physiologically evolving pattern of behavior shapes the character traits of both individuals and future generations.

\section{MATERIALS and METHODS}

Violence in brain by neuroplasticity

Two-step process will be explained in this study to expose the claims mentioned above. In the first phase; the causes of violence were discussed by reviewing the researches on physiological methods of learning and memory, and deleting the disturbing memory by depending also on the physiological procedures. In the second phase; two models have been offered to be applied for "the prevention of violence". The first model is to suppress the violence by loading new issues such as fine arts, music, philosophy, sports e.g., that does not contain violence and cause to forget the violence-related old memories. The second model is more forcing but effective. In that method, electrical stimulation on the brain of the humans is used to suppress the centers which are related with violence. For each model the expected scientific and medical results and procedures are planned to be evaluated in terms of medical ethics. These results, together with the analysis of science fiction books and personal interpretations, will be put forward in a philosophical and sociological way by conflicts.

\section{FINDINGS and EVALUATIONS}

\section{Learning the Violence}

Learning is a reflection of the acquired experiences and changing the behavior(4). How does a person gain knowledge? Why some information is remembered for a long time, while the others are forgotten? The information process approach suggests a model of how learning comes to fruition in the human mind in order to be able to answer these questions. This model is shown in Figure 1(5).

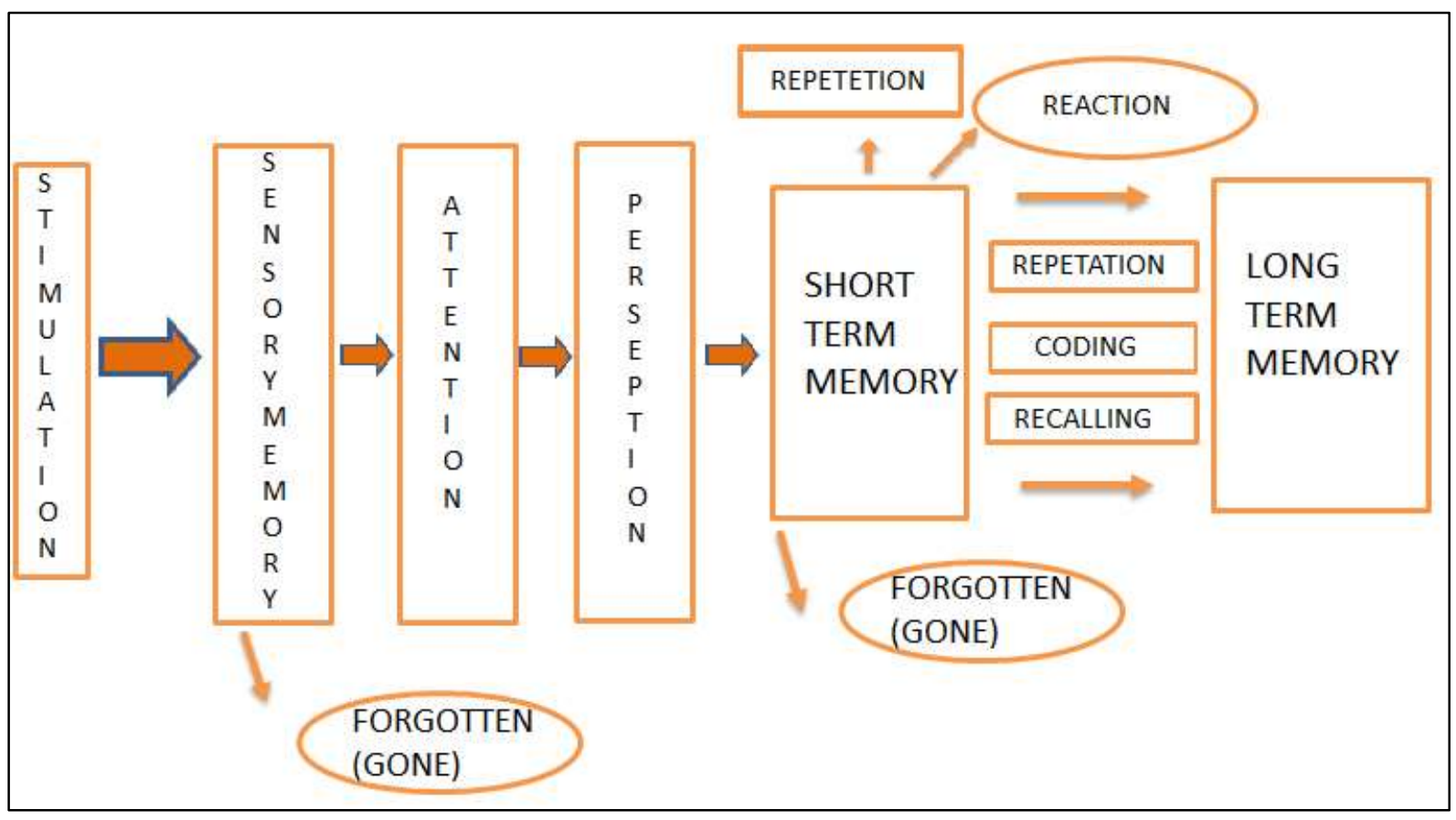

Figure 1. Mental Models of Learning

According to Hebb (1904-1985), there are two types of memory. These are a) short-term memory and b) Long-term memory. However, some scientists add "sensory/immediate" memory to short-term memory types(5):

1. Sensory/Immediate memory is the working memory and related with the incoming environmental impulses. This is the information that is being used at any instant. For example, when we put our hand on to ice, and then withdraw it, the feeling of coldness lasts for a few seconds in our hand. The physiological mechanism playing a role in the working memory is the reverberating circuit formed in the prefrontal cortex. It continues for a very short period of time, such as a few seconds, and after the coming of a new sensory knowledge, it is deleted.

2. Short-term memory is characterized by keeping the information in mind for period, varying between seconds and hours. For example, even if a phone number has been heard for once, it can be kept in mind for several hours if it is very important for the person.

Short-term memory is formed in the hippocampus and the adjacent parahippocampal portions of the medial temporal cortex by presynaptic facilitation, and post tetanic potentiation mechanism. As long as the reverberating neural activity continues, short-lived knowledge is remembered. The short-term memory decreases and disappears depending on the time. But in some case, some important and intense information in the short-term memory can be transferred to the long term memory.

3. Long-term memory (secondary memory) is storing information for months, years or even for the entire life in the memory. Some information forming the short-time memory can turn into the permanent memory by being strengthened (consolidation). Hence, the several components belonging to the memory are located in the sensory cortical areas (related to visual, auditory, olfactory, somatosensory and other senses) or motor cortical areas. 
There are strong neural links (engrams) between these components and one of their activation can easily activate the entire engram which their neurons have low threshold. In the formation of long term memory, structural changes occur both in the presynaptic neurons and postsynaptic neurons (Hebb's rule) that convey the information. For this, new protein syntheses are required (neural plasticity). By means of the glutamate and long-term potentiation (LTP) mechanism, some new gene expressions in the presynaptic and postsynaptic cells occur, and new protein synthesis develop. New synaptic connections are generated with these structural changes.

In the cellular basis of long-term memory, the synaptic links between neurons of the components of the information should be reinforced. For this, the number of axon terminals synapsing on the postsynaptic neuron, synaptic nodes, neurotransmitters, dendrites and the receptor on the post synaptic cells should be increased. Hence, the summation of EPSPs drops their threshold. When some of the neurons constituting the knowledge are being stimulated, the entire pathway (engram) may be activated. For new protein synthesis, new gene expressions which called immediate early genes (IEGs) in the presynaptic and postsynaptic cells' nuclei should take place. Therefore, neurons bind tightly to each other and lower the stimulating threshold for any incoming warning and the relevant memory is remembered. For example, someone who sees a white hair similar to her grandmother can remember all the memories about her/his grandmother(6-8).

\section{Neural Plasticity in Learning}

Until 1960, it was thought that there was no proliferation in neurons and, the nervous system did not show any improvement after adulthood. In the late 19th century, Ramon y Cajal (1852-1934) observed that, cortical regions of experimental animals grew by exposure to colorful and rich visual and auditory stimuli after birth. They have more developed and thicker cortices than others which has no any stimulation during growing up. Afterwards, it is described that the brain has ability to change its capacities throughout the life depending on the learning and an individual's experience. Thus, the proportion of grey matter can change, and synapses may strengthen or weaken over time. It is called neural plasticity(4).

\section{Memory Neurochemistry and 'Immediate Early Genes'}

The newly learned knowledge can become persistent and can even cause some epigenetic changes in the brain if it is too impressive or strong(4).

The epigenetic term, which was first proposed by Conrad Waddington in the 1950 s, is today defined as; the study of heritable changes in gene function that do not involve changes in the DNA sequence(9). In the original sense of this definition, epigenetics referred to all molecular pathways modulating the expression of a genotype into a particular phenotype(10). Neuroepigenetic, refers to the mechanisms and processes that allow epigenome in the nondividing cells of the nervous system to be regulated by experience(11).

Researches show that, epigenetic changes that are caused by the environment and social relations transferred to the permanent genes in the parents by IEGs (immediate early genes) and can also pass from parents to offspring. Recently, it has been realized that early prenatal and postnatal environmental effects including maternal behavior, can lead to persistent chromatin modifications in the form of methylation of the baby's genes that encode hormones, growth factors and receptors. This can affect learning, memory and emotional states of the children. Moreover, females that experienced maltreatment during infancy or childhood later can transfer this methylated genes to her off springs which might have some psychological disorders such as anxiety. A father also can inherit his horrors which he lived in the battle, to his son as an anxiety syndrome. This knowledge brings to mind that, modern families that have good experiences, intelligent education, fine arts, sports, musical habits can cause to have good generations in the future as it is seen in the developed countries(4,7-8). For example, in developing countries is said that, "the new generation is very smart". This is scientifically refers to the Flynn's effect which is the substantial and long-sustained increase in both fluid and crystallized intelligence test scores that was measured in many parts of the world over the 20th century(12). From this point of view of epigenetic, the smart babies can be understandable because they are not coming from the families that are struggling with violent life instead; they are coming from the families that are having good conditions and peace.
Since the etiology of violence depends on one's experience and his/her genes, the treatment methods should start with changing these experiences and changing the genetic activity by epigenetic acquisition. If environmental impulses could change one's brain by means of neural plasticity forcing to learn the good skills, and forcing to be a good person, we could have decreased the violence in the next generations(5). May be the violence in that community could be erased and from the brains. The mechanisms of forgetting of some knowledge could be explained by the following theories:

1.Corruption theory says that, "the knowledge which is out of sight out of mind". If the stimulant that takes action is kept away from the organism, forgetting process begins. The physiological mechanism that plays a role in deleting a knowledge is weak and low frequency stimuli $(<20 \mathrm{~Hz})$ which leads to the synthesis of protein phosphatases instead of protein kinases. This plays a role in protein degradation and hence, the synapses are weakened and even die.

2. Mixture theory says that, the newly learned intense topics decrease the importance of others. This mechanism can be explained as physiologically that; each prominent impulse in the nervous system tries to inhibit the other impulse transmission by way of presynaptic and lateral inhibitions.

3. Motivated forgetting says that, emotional and physical traumas associated with punishment and fears are intentionally suppressed by the cortex(4-5).

In the scientific experiments, it is proven that there was a decrease in learning and destruction in memory due to high level of stress. In another experiment, when ventromedial nucleus known as rewarding center was electrically stimulated, the animals continue to push the stimulating lever(4).Thus, stimulation of the rewarding center had motivated the animal's behavior(5).The result here the hypothesis of motivation and rewarding to the animals or human beings is an effector factor to teach them good behaviors and values.

Evaluation of Methods Used and Conclusions with Regard to Ethical-SocialLegal Aspects

Humankind can create a non-violent community with etiology-based violence treatment. When we are about to start treatment, we encounter with Medical ethics. Medical ethics is a system of moral principles that apply values to the practice of clinical medicine and in scientific research. More Generally, Medical Ethics is a system of moral principles that apply values to the practice of clinical medicine and in scientific research (13). This project aims not only to cure individual violence, but also to create a peaceful and having good moral values society by preventing violent impulses. In our daily life, we adults and even our children are having a systematic violence education successfully implemented by television or other mass media, causing us forcibly witnessing violence and to learn quite different techniques of harming others. According to the first model, the needs to be done depending on corruption and mixture theory; is to encourage, emphasize, insist on and repeatedly teach the moral, scientific and artistic values that are valid for all periods of history and for all people. With these technics, mankind, which creates permanent memory, will first learn good ethics, knowledge, art literature and philosophy, then process them into their genes and transmit them to their grandkids. Violence, having been unused information, will be forgotten.

But the problem here is "what is the universal good?" For example, in Sparta, the most powerful city state in Ancient Greece, the children who steal, were perceived as the "evidence of the courage"(14). If the people in the ancient Greek had used the principles of neural plasticity as we mentioned, they would glorify the robbery as a good virtue, and perhaps make the good virtues of the 21st century, different from the present. In this example we realize that, there is no common universal goodness to be passed on to generations. Maybe in the future, to have more fortune and more food to eat than the poor and miserable people would be considered non-virtues behaviors.

Nowadays, by the hand of the parents, newborn children will have more facilities in the arts and sports as good values of today's trends. But, gradually, there will be prototype children will be grown up. Ethical good means that the actions are freely chosen. Is it acceptable for the person to have good moral values even if he/she couldn't decide what to do and what to be? This project supports to take the free choice of human beings. 
Inequality in societies causes other problems. It is difficult to tend to art, science and philosophy for the countries that struggle with hunger, wars and diseases. On one hand, there are developed countries by their qualified intellectual capacities that they can use these abilities, by mistake, against the poor people for example, during the progression of scientific experiments or so.

To solve that inequality between countries, the executive team which includes people from all around the world can supervise this big project. But the problems do not end here either. While the supervisory team change the perception of society to the direction of the good virtues; do they use the methods to create a ready-made package of citizens who accept everything and do not resist anything? In addition, even if violence is eradicated from the social memory, supervisor's control ambition could be a cause of violence among themselves for the sake of power?

Second Model is related to suppression of Violent Behavior by using Rewarding and Punishment Systems. The second model can solve the 'common virtue' problem discussed above. When a subject gets angry or pretend to show aggression, violent behavior can be stopped. Sometimes rewarding or punishing cannot be enough in every society due to their culture. For example, in certain societies, the "macho" attitudes of young children (especially boys) are praised by both their peers and their parents. For this reason, to improve the people's moral values some medical experimental solutions must be used.

It is shown that amygdala is responsible for fear, rage and anger(4). If we place a chip into the human brain, that senses increased excitation in amygdala due to violence, we can suppress that excitation by secretion some neurotransmitter that can inhibit amygdala. Moreover, we can also stimulate the rewarding (pleasure) center to focusing the person to another aspect.

Similar study was done in animals. When the rewarding center, such as the basal fore brain band, ventromedial nucleus of an animal were electrically stimulated, it was seen that, they continued to press the lever to activate the pleasure center(4). In this way, to reinforce by stimulating the appropriate brain centers is possible to produce good activities.

However, it has been shown that there are differences in behavior when the animal's rewarding center is stimulated by its own satisfaction or by artificial electrical stimulation(6). In the case of classical reinforcement, when the animal is satisfied by eating or drinking or making sex, there is no need to be rewarded again and again. If the reward center is stimulated by direct electrical stimulation, the animal cannot reach to satisfaction immediately and tries to continue. This will cause the anorexia, because it rejects even eating. In addition, the extreme stimulation of the rewarding centers causes the electrical activity to spread to the nearby "punishment center" and, generates anger. Accordingly, while mild stimuli create satisfaction and pleasure, stronger stimuli create a penalty effect. Thus, using a very intensive stimulation for rewarding, we cause to unfavorable effect so, desired behavior becomes a behavior to be avoided(5).

The second model cannot be used for all societies because of the cost and effectivity. It can be started with the guilty people who are prone to violence, i.e. prisoners can be considered for the experiment. However, nowadays, investigations on prisoners are limited because of their inclusion to 'special groups in clinical research ethic' which it is not permitted to investigate on them. Moreover, their informed consent might be invalid because of their not being independent in their decisions(15-16). Nevertheless, if we apply these procedures to the prisoners, they will have a lot of problems when they are get out the prison.

Anthony Burgess's book called 'Automatic Orange' guides the assumptions in this regard. The story depends on a project to rehabilitate the aggressive prisoners by giving them nauseous drugs while watching violent scenes. This procedure was succeeded in a volunteer (Alex) who stopped aggression after 20 days of treatment. After getting out of the prison, he could not react against the provocations showed by his friends and the other people. As a result, although he cannot show any violence, he stayed undefended in the life. His past enemies find Alex and beat him. Alex had lost his ability of self-defense with the treatment(17).

Turkish (article 25/1) and some other countries' "Criminal Law" states that; self-defense of a person is exempted from punishment as normal for human nature(18). Also, World Medical Association Declaration of Helsinki says that; the duty of the physician in medical research to protect the life, health, privacy, and dignity of the human subject. Now Alex cannot take advantage of the rights granted to him by the Declaration of Helsinki, because he lost his ability to protect his life, his health, his dignity, his integrity, his selfdetermination and his privacy(19).
In addition, another view of point in the book is treatment for the prisoners could be annoying because the crime must be punished but turning them into good people could undermine societies' confidence for their criminal systems(17).

\section{DISCUSSION}

Although the idea of creating a non-violent community appears pleasant and comfortable, Charles Darwin (1809-1882), the founder of the idea of evolution says that; "Life is a struggle; there is natural selection; it is true that the strong destroy the weak in order to survive" (20). Epigenetic changes and prevention of violence with learning mechanisms have the possibility of creating stereotyped community. This community may encounter of extinction by being vulnerable in the wild-world and being weakened in the face of natural and other disasters. Their ability of problem solutions might lessen due to their comfortable life.

Also, Marx (1818-1883) and Engels (1820-1895) argued "that violence played a revolutionary role in history. The factor that drives historical development is a class struggle. They argued that violence creates dynamism in community and that it was necessary for social development (21). Sometimes the violence or other type of iniquity can generate a social reaction in the community and it leads to improvements in the society and triumphs against the injustice. The pathways of preventing the violence may cause regression of our civilization, and destruction of cultural differences. In such a case, where do the differences and dynamics that support the evolutionary process arise from? This question is important because in philosophy, it is said that; "beginning the proposition called a thesis, a negation of that thesis called the antithesis, and a synthesis whereby the two conflicting ideas are reconciled to form a new proposition"(22).

But, should we discourage our brains from being educated towards "today's good values in considering all these inferences?

There are four ethical approaches (Kantian, Utilitarian, Communitarian, and Liberal), which are accepted for many years by the modern world, should be remembered to make decision between good and bad (23). In the Kantian approach, the goal that is set on at the beginning of the pathway is crucial, even if it cannot be reached the aim. The Utilitarian approach, "the action that provides the greatest number of well-being is good and, small number of people' suffering, can be neglected." In the Communitarian approach, "the action that will cause every individual who makes up the society to get better is the best." In the liberal approach, it is said that "each individual gets his/her deserved improvement according his/her personal qualities and sufficiency"(23).

As a conclusion every people will behave and educate their children due to its cultural society and the conditions of the environment and to the rules of their state, but must know that these features will be transferred to their offspring and the next generations.

\section{Conflict of interest}

No conflict of interest was declared by the authors.

\section{REFERENCES}

1. Ertekin, K. Geçmişten Günümüze Saldırganlığın Etkileri. Psikoloji, Ruh Sağlığı ve Hastalıkları Makaleleri Kütüphanesi, Url: http://www.Tavsiyeediyorum.Com/Makale 13455.Htm/22.04.2016.

2. David G., Preventing Violence In Structurally Violent Society: Mission Impossible, American Journal of Orthopsychiatry, 1996; 66:77-84

3. Türkçapar, M. H. Şiddet Ve Düşünce. Başka/Psikiyatri ve Düşünce Dergisi, İstanbul, 2009;3:90-102.

4. Pinar, L. Yörükan T., Higher Function Of The Cerebral Cortex, Summary of Nerve And Muscle Physiology, Ankara, Akademisyen Kitapevi, 2017;27595.

5. Temiz, B. Hatırlama ve Unutma. 2002. Access Address: http://W3.Gazi.Edu.Tr/ Burak/Odevhatirlamaunutma.Pdf/ 23.04.2016.

6. Pinar, L. Yörükan T., Synaptic Transmisson, Summary of Nerve and Muscle Physiology, Ankara, Akademisyen Kitapevi, 2017; 91-113.

7. Kandel, E., Schwartz, J., Jessell, T., Siegelbaum, S., Hudspeth, A. Cellular Mechanisms of Implicit Memory Storage And The Biological Basis Of Individuality. Principles Of Neural Sciences, 5.Edition, 2013, United States Of America, Page: 1460-86. 
8. Kandel, E. Schwartz, J., Jessell, T., Siegelbaum, S., Hudspeth, A. Prefrontal Cortex, Hipocampus and The Biology Of Explicit Memory Storage. Principles Of Neural Sciences, 5.Edition, 2013, United States Of America, Page: 1487-520.

9. Kapancik, S. Öğrenme Ve Belleğin Epigenetik Kontrolü. Url:Http://Bilimvebilimadami.Com/Ogrenme-Ve-Bellegin-EpigenetikKontrolu/ Access Date: 07 March 2015,

10. Dupont C, Armant Dr, Brenner Ca (September 2009). "Epigenetics: Definition, Mechanisms And Clinical Perspective". Seminars In Reproductive Medicine. 27 (5):351-357.

11. Orcan, S. Epigenetik Ve Epigenomik. Hacettepe Üniversitesi 2006, Url: Http://Yunus.Hacettepe.Edu.Tr/ Mergen/Derleme/D_Epigenetik.Pdf

12. Flynn Effect, Wikipedia, The Free Encyclopedia, Url: Http://Www.WikiZero.Co/Index.Php?Q=AhrOchm6ly9lbi53awtpcgvkaweub3jnl3dpa2kvrm x5bm5fzwzmzwn0 Access Date:31.08.2018

13. Beauchamp J. (2013), "Principles of Biomedical Ethics", Principles of Biomedical Ethics, 7.

14. Dikyol Ç. Derya, Sparta: An Educational Model From Ancient Greece, Mediterranean Journal Of Humanities Mjh.Akdeniz.Edu.Tr Vi/2 2016;189207,

15. Çobanoğlu, N. Hasta Hakları, Kuramsal Ve Uygulamalı Tıp Etiği. 1. Baskı, Ankara, Eflatun Yayınevi, 2009;43-60
16. Çobanoğlu, N. Kısıtılır Ve Özel Gruplarda Klinik Araştırma Etiği, Kuramsal Ve Uygulamalı Tıp Etiği. 1. Baskı, Ankara, Eflatun Yayınevi, 2009;123-8.

17. Burgess, A., A Clokwork Orange (Otomatik Portakal). Editör: Handan Akdemir, 2. Baskı, Kültür Yayınları, February 2005, İstanbul.

18. Turkish Criminal Code Law Nr. 5237 Passed On 26.09.2004 (Official Gazette No. 25611 Dated 12.10.2004)

19. World Medical Association Declaration of Helsinki Ethical Principles For Medical Research Involving Human Subjects, 64th Wma General Assembly, Fortaleza, Brazil, October 2013

20. Diane B. Paul, The Selection of The "Survival Of The Fittest", Journal Of The History Of Biology, Vol. 21, No. 3 (Autumn, 1988), Pp. 411-24, Published By: Springer Stable Url: Http://Www.Jstor.Org/Stable/4331067

21. Tarhan, N. Şiddet Hak Arama Yöntemi Midir? Zafer Dergisi, Sayı:282, Access Address: Http://Www.Abchukuk.Com/Makale/Makale24.Html/25.04.2016.

22. Hegel's Thesis-Antithesis-Synthesis Model" Encylopedia of Sciences and Religions. Berlin:Springer. 2013. Retrieved 11 September 2016.

23. Çobanoğlu N. Felsefedeki Etikten Tıbbi Etiğe, Kuramsal Ve Uygulamalı Tıp Etiği. 1. Baskı, Ankara, Eflatun Yayınevi, 2009, 9-21. 